\title{
GAS CHROMATOGRAPHY - MASS SPECTROMETRY ANALYSIS, INDUCTIVELY COUPLED PLASMA MASS SPECTROMETRY INVESTIGATION, AND ANTIMICROBIAL SCREENING OF CAESALPINIA BONDUCELLA (L.) ROXB SEED KERNEL
}

\author{
ALI ALRABIE, OLA BASA'A R, MAZAHAR FAROOQUI* \\ Department of Chemistry, Dr. Rafiq Zakaria College for Women, Aurangabad, Maharashtra, India. Email: mazahar_64@rediffmail.com \\ Received: 15 January 2019, Revised and Accepted: 20 March 2019
}

\section{ABSTRACT}

Objective: The objective of this study was to determine heavy metals using inductively coupled plasma mass spectrometry (ICP-MS) and phytochemical constituents of methanol extract of Caesalpinia bonducella seed kernel using gas chromatography - mass spectrometry (GC-MS).

Methods: In GC-MS investigation, 95\% methanol extract of $C$. bonducella seed kernel was performed on JEOL GC MATE II, column HP 5 MS, and Quadruple, double-focusing mass analyzer. Determination of heavy metals from C. bonducella powder was performed using Thermo scientific I CAP Q instrument, for plant powder digestion Anton Paar Microwave model: Multiwave 300 was used. Antimicrobial activity was evaluated using microdilutions broth method.

Results: GC-MS analysis of methanol extract of $C$. bonducella seed kernel has shown 11 different phytoconstituents. ICP-MS analysis has shown the concentration of ten heavy metals in C. bonducella seed kernel as follows: Cr 1.5 ppm, Fe 72.72 ppm, Co 0.33 ppm, Ni 3.03 ppm, Cu 10.73 ppm, Zn $18.44 \mathrm{ppm}$, As 0.03 ppm, Cd $0.02 \mathrm{ppm}$, and $\mathrm{Pb} 0.58 \mathrm{ppm}$.

Conclusion: Result showed that the plant is safe to use from toxic heavy metals such as $\mathrm{As}, \mathrm{Cd}$, and $\mathrm{Pb}$. It is suitable to check frequently the heavy metal content in the plant used in traditional medicines before given to patients.

Keywords: Heavy metals, Caesalpinia bonducella, Inductively coupled plasma mass spectrometry, Gas chromatography - mass spectrometry.

(c) 2019 The Authors. Published by Innovare Academic Sciences Pvt Ltd. This is an open access article under the CC BY license (http://creativecommons. org/licenses/by/4. 0/) DOI: http://dx.doi.org/10.22159/ajpcr.2019.v12i4.32067

\section{INTRODUCTION}

Medicinal plants have been used for the treatment of various diseases from ancient time and have been playing an important role in the discovery of the modern day medicines with novel chemical constituents [1]. In the U.S.A., about $8 \%$ of hospital admissions are due to side effects of synthetic drugs [2]. Nowadays, the use of herbal medicines for the treatment of various diseases expands continuously because people believe that herbal medicines have no toxic effects and they are safe to use [3]. Medicinal plants contain both organic and inorganic constituents [4]. Heavy metals are those metals which have relative atomic number $>\mathrm{Na}$ and density $>5 \mathrm{~g} / \mathrm{cm}^{3}$ [5]. Plants need some of the heavy metals for their structural and biological functions such as $\mathrm{Zn}, \mathrm{Cu}, \mathrm{Ni}, \mathrm{Mn}, \mathrm{Cr}$, and $\mathrm{Fe}$; these elements are considered as essential trace elements [6] whereas toxic elements which have unknown biological role in the plant such as $\mathrm{Cd}, \mathrm{As}, \mathrm{Hg}$, and $\mathrm{Pb}$ are toxic even at low concentration [7]. Heavy metals are present in medicinal plants in different concentrations, and these levels are influenced by several factors such as type of plant, the type of soil, the climate, and the type of agriculture [8]. The human body requires trace elements in very minute quantities to maintain good health, proper body functions, and development $[9,10]$. It gets translocated to human through the use of medicinal plants grown in contaminated environments, in which, soils, water, and air contain high concentration of heavy metals [11-14].

C. bonducella (L.) Roxb is belonging to the caesalpiniaceae [15], commonly known as Nata Karanja [16]. It is found throughout India and tropical countries in the world [17]. "Bonducella" is derived from the Arabic word "Bonduce" the meaning is "Little ball" [18]. There are several reports on phytochemical constituents of $C$. bonducella (L.) [17,19-21], but no work on metal constituents is reported earlier. The aim of this study is to determine heavy metals of $C$. bonducella (L.) Roxb seed kernel and to ensure its safe usage in herbal medicine.

\section{METHODS}

Collection of plant material: The $C$. bonducella seeds were purchased from local vendor at Aurangabad, India. It was authenticated by Dr. Narayan Panddhura, Department of Botany and Dr. B.A.M University - Aurangabad. Seeds were broken, and kernel from outer seed shell was separated.

Preparation of extract: Seed kernel of $C$. bonducella was ground to powder form and extracted with $95 \%$ methanol in a Soxhlet extractor for $6 \mathrm{~h}$; further, the extract was filtered and concentrated on rotary vacuum evaporator. Sticky, white extract was kept in an amber bottle in refrigerator for further use.

\section{GAS CHROMATOGRAPHY - MASS SPECTROMETRY (GC-MS)}

GC-MS investigation of methanol extract of seed kernel of $C$. bonducella was carried out under the following conditions: Instrument name: JEOL GC MATE II, column HP 5 MS, and Injector T $220^{\circ} \mathrm{C}$; carrier gas: High pure helium; flow rate: $1 \mathrm{ml} / \mathrm{min}$, oven temperature $50-250$ at $10^{\circ} / \mathrm{min}$, and Ion chamber at $250^{\circ} \mathrm{C}$.

\section{ICP-MS}

Microwave digestion

Plant powder digestion was carried out using Anton Paar Microwave model: Multiwave 300. Plant powder $(0.1 \mathrm{~g})$ was dissolved in $7 \mathrm{ml}$ $\mathrm{HNO}_{3}\left(37 \%\right.$, Merck) and $1 \mathrm{ml} \mathrm{H}_{2} \mathrm{O}_{2}(30 \%$, Merck), and the vessel was immediately closed to avoid contamination. The sample was hold for $25 \mathrm{~min}$., zero ramp time at 400 watts and then retained for $30 \mathrm{~min}$., 5 ramp at 500 watts. After cooling, the vessel was opened, and the solutions were diluted to $100 \mathrm{ml}$ with Milli Q water (Thermo scientific, Barnstead, smart 2 pure). The vessel was closed and shaken thoroughly to complete the dissolution. 
Elemental measurement using ICP-MS

ICP-MS instrument (iCAP Q, Thermo fisher scientific, USA) was used for measuring the concentration of elements in the digested sample solution under the following conditions: Plasma RF forward power 1548.6 W, sample uptake: $30 \mathrm{~s}$, cool flow read back: $13.67 \mathrm{~L} / \mathrm{min}$, nebulizer flow: $1.0180 \mathrm{~L} / \mathrm{min}$, auxiliary flow read back: $0.796 \mathrm{~L} / \mathrm{min}$, integration time: $10 \mathrm{~s}$, peristaltic pump speed: $40 \mathrm{rpm}$, sampler and skimmer cones: $\mathrm{Ni}$, and analysis mode: eQuant.

\section{Chemical reagents and analytical method}

Deionized water of 18.2 megaohm was used for dilution and sample preparation. The external calibration solutions were prepared from standard certified multielements solutions (Merck, USA). Stock solution was prepared from a mixture of 30 elements at concentration of $10 \mathrm{ppm}$ from Merck. A concentration of $25 \mu \mathrm{g} / \mathrm{l}$ of yttrium (Y) or iridium (Rh) was used as internal standard for the analysis. Y was used for low mass elements such as $\mathrm{Cr}, \mathrm{Co}, \mathrm{Cu}$, and $\mathrm{Zn}$, whereas $\mathrm{Rh}$ was used for high mass elements such as $\mathrm{Cd}$ and $\mathrm{Pb}$. A tune solution (BICAP) containing $\mathrm{Li}, \mathrm{Co}$, In, and $U$ was used for performance validation and instrument tuning, which contains $1 \mu \mathrm{g} / \mathrm{l}$ of each element in $2 \% \mathrm{HNO}_{3}$ and $0.5 \% \mathrm{HCl}$.

\section{Evaluation antibacterial and antifungal activity}

Microbroth dilution method was used to determine the minimum inhibitory concentration (MIC) of methanol extract of $C$. bonducella seed kernel. Four strains of gram bacteria were used; two Gram-positive bacteria (Staphylococcus aureus MTCC 96 and Streptococcus pyogenes MTCC 442) and two Gram-negative bacteria (Escherichia coli MTCC 443 and Pseudomonas aeruginosa MTCC 1688), for fungi: Candida albicant (MTCC 227), Aspergillus niger (MTCC 282), and Aspergillus clavatus (MTCC 1323) were used. All MTCC cultures were collected from Microcare Laboratory, Surat. Ampicillin, chloramphenicol, ciprofloxacin, and norfloxacin were used as standard antibacterial drugs, whereas nystatin and griseofulvin were used as standard antifungal drugs. Test microorganisms and growth media, sample preparation, and MIC were determined as standard method [22].

\section{RESULT AND DISCUSSION}

\section{GC-MS investigation}

GC-MS analysis result Figure 1 of methanol extract of $C$. bonducella seed kernel (MCBSK) was showed 11 peaks indicating the present of 11 different phytoconstituents. The library search was indicated the presence of following compounds in this extract: $2,4\{1 \mathrm{H}, 3 \mathrm{H}\}$ pyrimidinedione, dihydro-3-methyl, benzene, $\{1$-methylenebutyl $\}$-, benzidine, á-neoclovene, flavone, 3,6-non-adienedioic acid, 5,5-dimethyl dimethyl ester, 9,12-octadecadienoic acid\{Z,Z\}, octadecanoic acid, 3-oxo, methyl ester, isopropyl stearate, 9,12 octadecadienoic acid $\{Z, Z\}, 2,3$-dihydroxypropyl ester, 9,12,15-octadecatrienoic acid, and 2,3-dihydroxypropyl ester $\{Z, Z, Z\}$.

Photochemical constituents' retention time value, area, area \%, peak height, molecular formula, molecular weight, and identified compound name are shown in Table 1 . The results were revealed that 9,12-octadecanoic acid (Z, Z) (23.953\%) at RT (19.67); octadecanoic acid, 3-oxo, and methyl ester (11.542\%) at RT $(21.28 \%)$; flavone $(11.09 \%)$ at RT (17.75); and 3,6-non-adienedioic acid and 5,5-dimethyl dimethyl ester (9.99\%) at RT (18.7) were found as a major components of MCBSK. We found that the majority of components were fatty acids and their derivatives. Total area percentage of six fatty acids or their derivatives (RT 18.7, 19.67, 21.28, 22.92, 24.35, and 25.3) is $71.36 \%$. 9,12-octadecanoic acid (Z,Z) has been reported to have many biological activities such as anti-inflammatory, hypercholesterolemic activity,

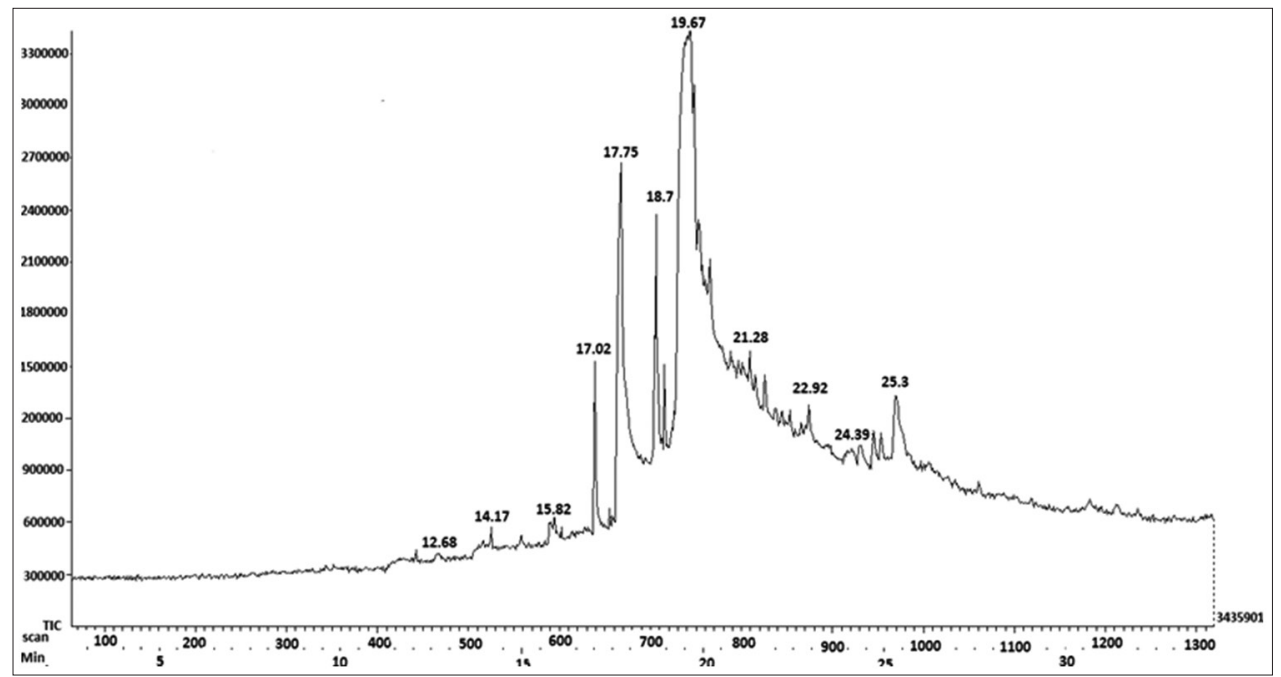

Fig. 1: Gas chromatography - mass spectrometry chromatogram of methanol extract of Caesalpinia bonducella seed kernel

Table 1: Phytochemicals compounds identified in methanol extract of Caesalpinia bonducella seed kernel

\begin{tabular}{llllllll}
\hline S. No. & R.T (Min) & Peak area & Area \% & Height & $\begin{array}{l}\text { Molecular } \\
\text { weight } \mathbf{( g / m o l} \text { ) }\end{array}$ & $\begin{array}{l}\text { Chemical } \\
\text { formula }\end{array}$ & Probable compound \\
\hline 1 & 12.68 & 8608645 & 3.149 & 420082 & 128 & $\mathrm{C}_{5} \mathrm{H}_{8} \mathrm{~N}_{2} \mathrm{O}_{2}$ & $2,4\{1 \mathrm{H}, 3 \mathrm{H}\}$-pyrimidinedione, dihydro-3-methyl \\
2 & 14.17 & 10298439 & 3.77 & 570956 & 146 & $\mathrm{C}_{11} \mathrm{H}_{14}$ & Benzene, \{1-methylenebutyl\}- \\
3 & 15.82 & 11758505 & 4.302 & 604553 & 184 & $\mathrm{C}_{12} \mathrm{H}_{12} \mathrm{~N}_{2}$ & Benzidine \\
4 & 17.02 & 14631809 & 5.353 & 1524914 & 204 & $\mathrm{C}_{15} \mathrm{H}_{24}$ & á-neoclovene \\
5 & 17.75 & 30300375 & 11.09 & 2692186 & 222 & $\mathrm{C}_{15} \mathrm{H}_{10} \mathrm{O}_{2}$ & Flavone \\
6 & 18.7 & 27304042 & 9.99 & 2371347 & 238 & $\mathrm{C}_{14} \mathrm{H}_{22} \mathrm{O}_{3}$ & 3,6-Non-adienedioic acid, 5,5-dimethyl dimethyl ester \\
7 & 19.67 & 65474434 & 23.953 & 3435901 & 280 & $\mathrm{C}_{18} \mathrm{H}_{32} \mathrm{O}_{2}$ & 9,12-octadecadienoic acid $\{\mathrm{Z}, \mathrm{Z}\}$ \\
8 & 21.28 & 31550935 & 11.542 & 1565542 & 312 & $\mathrm{C}_{19} \mathrm{H}_{36} \mathrm{O}_{3}$ & Octadecanoic acid, 3-oxo, methyl ester \\
9 & 22.92 & 24741051 & 9.051 & 1276576 & 324 & $\mathrm{C}_{21} \mathrm{H}_{42} \mathrm{O}_{2}$ & Isopropyl stearate \\
10 & 24.35 & 21560304 & 7.89 & 1060147 & 354 & $\mathrm{C}_{21} \mathrm{H}_{38} \mathrm{O}_{2}$ & 9,12 -octadecadienoic acid $\{\mathrm{Z}, \mathrm{Z}\}$-, 2,3-dihydroxypropyl ester \\
11 & 25.3 & 24422286 & 8.934 & 1329418 & 352 & $\mathrm{C}_{21} \mathrm{H}_{36} \mathrm{O}_{4}$ & $9,12,15$-octadecatrienoic acid, 2,3-dihydroxypropyl ester $\{\mathrm{Z}, \mathrm{Z}, \mathrm{Z}\}$ \\
\hline & & & & & & &
\end{tabular}


cancerpreventive, hepatoprotective,anti-acne,antiarthritic,anticoronary, antiandrogenic, and antihistamine [23]. 9,12,15-octadecatrienoic acid and 2,3-dihydroxypropyl ester $\{\mathrm{Z}, \mathrm{Z}, \mathrm{Z}\}$ have been reported to have antiinflammatory and central nervous system depressant activity [24].

\section{ICP-MS}

The result of ICP-MS study of CBSK is summarized in Table 2. This study was designed to investigate the concentration of ten heavy metals ( $\mathrm{Cr}, \mathrm{Mn}, \mathrm{Fe}, \mathrm{Co}, \mathrm{Ni}, \mathrm{Cu}, \mathrm{Zn}, \mathrm{As}, \mathrm{Pb}$, and $\mathrm{Cd}$ ). The result shows that the concentrations of heavy metals of CBSK range between $0.02 \mathrm{ppm}$ for $\mathrm{Cd}$ and $72.72 \mathrm{ppm}$ for $\mathrm{Fe}$, and the order of concentration of these ten heavy metals is $\mathrm{Fe}>\mathrm{Mn}>\mathrm{Zn}>\mathrm{Cu}>\mathrm{Ni}>\mathrm{Cr}>\mathrm{Pb}>\mathrm{Co}>\mathrm{As}>\mathrm{Cd}$.

Increase in use of fertilizers and other chemicals to meet the higher demands of food production or human consumption [25]; industrial activities and transportation activities lead to increase of heavy metals pollution. Numerous studies have investigated the presence of toxic contaminants in medicinal plants. The World Health Organization (WHO) recommends that medicinal plants should be tested for heavy metals content before exporting, and heavy metals should remain within permissible limits [26]. Fe is an essential element for the human body and plays essential function in the production of hemoglobin and in the oxygenation of red blood cell [27]. Fe concentration was observed in this study at $72.72 \mathrm{ppm}$ with the highest concentration compared to other heavy metals concentrations. The WHO has not established the limits of Fe in medicinal plants and Fe concentration

Table 2: Concentration of heavy metals in seed kernel of Caesalpinia bonducella

\begin{tabular}{llll}
\hline S. No. & $\begin{array}{l}\text { Element } \\
\text { symbol }\end{array}$ & $\begin{array}{l}\text { Atomic weight } \\
\text { (g/mol) }\end{array}$ & $\begin{array}{l}\text { Concentration } \\
\text { (ppm) }\end{array}$ \\
\hline 1 & $\mathrm{Cr}$ & 51.996 & 1.50 \\
2 & $\mathrm{Mn}$ & 54.938 & 19.77 \\
3 & $\mathrm{Fe}$ & 55.845 & 72.72 \\
4 & $\mathrm{Co}$ & 58.933 & 0.33 \\
5 & $\mathrm{Ni}$ & 58.693 & 3.03 \\
6 & $\mathrm{Cu}$ & 63.546 & 10.73 \\
7 & $\mathrm{Zn}$ & 65.390 & 18.44 \\
8 & $\mathrm{As}$ & 74.922 & 0.03 \\
9 & $\mathrm{Cd}$ & 112.411 & 0.02 \\
10 & $\mathrm{~Pb}$ & 207.200 & 0.58 \\
\hline
\end{tabular}

in CBSK higher than the permissible limit set by (Food and Agriculture Organization) FAO/WHO in edible plants (20 ppm) [28]. Fe deficiency causes anemia [29]. $\mathrm{Cu}$ is very important with $\mathrm{Fe}$ for the synthesis of hemoglobin and in regulation of immune function [30], is a component of several enzymes [31], is required for maintaining a health of heart and blood vessels [32], and is also required for antioxidant protection [33]. $\mathrm{Cu}$ was found in this plant $10.73 \mathrm{ppm}$, the WHO permissible limits of $\mathrm{Cu}$ in medicinal plants have not established, but national limits of $\mathrm{Cu}$ in Singapore for herbal medicines and products are $150 \mathrm{ppm}$ [34]. Zn plays an important role in various cell processes [35] and has following three critical functions: Catalytic (Zn can activate 300 enzymes), structural (Zn plays a role in maintaining protein structure and DNA), and regulatory [36]. Zn concentration in this present study was observed $18.44 \mathrm{ppm}$, which is below the permissible limit (27.4 ppm) reported by FAO/WHO in edible plants. Mn is very important for several enzymatic processes and in regulation of immune responses of the body by breakdown of amino acids [37]. Mn concentration in this study was observed (19.77 ppm), which is higher than the limit of Mn in edible plants ( 2 ppm) set by FAO/WHO (1984). The WHO has not established any limits for $\mathrm{Mn}$ in medicinal plants. $\mathrm{Ni}$ is required by the human body in trace quantity and plays an important role in the production of insulin in the pancreas. Nickel has been reported to cause many diseases in high concentration such as lung cancer, nasal, renal disorder, dermatitis, sinus, chronic bronchitis, acute respiratory, and pulmonary fibrosis [38]. The WHO has not established limit for Ni in medicinal plants; however, the limit for $\mathrm{Ni}$ in edible plants has been set by FAO/WHO $1.63 \mathrm{ppm}$. Concentration of Ni in this study was observed at $3.03 \mathrm{ppm}$. Co is required in trace quantity for human body and is a key constituent of cobalamin known as Vitamin $B_{12}$ [39]. The concentration of Co in the present study was observed at $0.33 \mathrm{ppm}$, and WHO has not established yet permissible limits for Co in medicinal plants. $\mathrm{Cr}$ plays an important role in glucose metabolism, maintaining the configuration of RNA and several enzymes can be activated by $\mathrm{Cr}$ [40], and $\mathrm{Cr}$ also is a vital component for insulin to stabilize blood sugar energy [41]. Cr concentration was observed $1.5 \mathrm{ppm}$ in this plant under study, which is below WHO limits in national Canada for herbal material 2 ppm. As, $\mathrm{Cd}$, and $\mathrm{Pb}$ are toxic metals and have no functions in the human body. Several countries including India, China, Canada, Thailand, Malaysia, and Singapore have established national permissible limits for Cd, As, and $\mathrm{Pb}$ in raw herbal material. In India, the permissible limits for $\mathrm{Cd}, \mathrm{As}$, and $\mathrm{Pb}$ in herbal material are $0.3 \mathrm{ppm}, 3 \mathrm{ppm}$, and $10 \mathrm{ppm}$, respectively, according to AYUSH [42]. In the present study, the concentration of

Table 3: Minimal inhibition concentration of methanol extract of Caesalpinia bonducella seed kernel

\begin{tabular}{|c|c|c|c|c|c|}
\hline \multicolumn{6}{|c|}{$\operatorname{MIC}(\mu \mathrm{g} / \mathrm{ml})$} \\
\hline S. No. & Extract code & $\begin{array}{l}\text { Escherichia coli } \\
\text { MTCC } 443\end{array}$ & $\begin{array}{l}\text { Pseudomonas aeruginosa } \\
\text { MTCC1688 }\end{array}$ & $\begin{array}{l}\text { Staphylococcus aureus } \\
\text { MTCC96 }\end{array}$ & $\begin{array}{l}\text { Streptococcus pyogenes } \\
\text { MTCC } 442\end{array}$ \\
\hline 1 & MCBSK* & 250 & 500 & 125 & 100 \\
\hline \multicolumn{6}{|c|}{ Standard Antibiotic } \\
\hline 2 & GEN & 0.05 & 1 & 0.25 & 0.5 \\
\hline 3 & AMP & 100 & - & 250 & 100 \\
\hline 5 & CIP & 25 & 25 & 50 & 50 \\
\hline 6 & NOR & 10 & 10 & 10 & 10 \\
\hline
\end{tabular}

*MCBSK: Methanol extract of Caesalpinia bonducella seed kernel, GEN: Gentamicin, AMP: Ampicillin, CMP: Chloramphenicol, CIP: Ciprofloxacin, NOR: Norfloxacin, MIC: Minimum inhibitory concentration

Table 4: Antifungal activity of methanol extract of Caesalpinia bonducella seed kernel

\begin{tabular}{lllll}
\hline \multicolumn{2}{l}{ Minimal fungicidal concentration $(\mu \mathrm{g} / \mathrm{ml})$} \\
\hline S. No. & Extract code & Candida albicants (MMTCC227) & Aspergillus niger (MTCC282) & Aspergillus clavatus (MTCC1323) \\
\hline 1 & MCBSK & 250 & $>1000$ & $>1000$ \\
Antifungal standard drugs & & & 100 \\
2 & NYSTATIN & 100 & 100 & 100 \\
3 & Griseofulvin & 500 & 100 & \\
\hline
\end{tabular}


$\mathrm{Cd}$, As, and $\mathrm{Pb}$ was found to be within permissible limits of AYUSH $0.02 \mathrm{ppm}, 0.03 \mathrm{ppm}$, and $0.58 \mathrm{ppm}$, respectively.

\section{Antibacterial and antifungal}

The methanol extract of $C$. bonducella seed kernel is screened for antibacterial and antifungal activities. The results are shown in Tables 3 and 4, respectively. It is observed that in the case of positive bacteria $S$. aureus, the extract shows high inhibition compared to standard drug (ampicillin) and less inhibition compared to other standard drugs. In the case of positive bacteria $S$. pyogenes, the extract shows moderate inhibition similar to the inhibition of standard drug (ampicillin). For antifungal activity, the extract shows moderate inhibition compared to inhibition of standard drug nystatin and high inhibition compared to inhibition of standard drug (griseofulvin).

\section{CONCLUSION}

Toxic heavy metals of As, $\mathrm{Cd}$, and $\mathrm{Pb}$ concentrations were found within Indian national permissible limits (AYUSH), whereas $\mathrm{Ni}, \mathrm{Cr}, \mathrm{Cu}$, and $\mathrm{Fe}$ concentrations are exceeded permissible limits in edible plants. GC-MS analysis of $95 \%$ methanol extract of $C$. bonducella seed kernel revealed that 11 different phytoconstituents are present, and the majority of these phytoconstituents are fatty acids or their associated derivatives. The methanol extract possesses good to moderate antibacterial and antifungal activities.

\section{AUTHORS' CONTRIBUTION}

Ali Alrabie and Ola Basa'ar carried out the experiment and wrote the manuscript. Dr. Mazahar Farooqui, the research supervisor conceived the original idea, supervised the project, and corrected the scientific content of the manuscript.

\section{CONFLICT OF INTERESTS}

The authors have no conflicts of interest.

\section{REFERENCES}

1. Bhanisana DR, Sarma HN. Profile of trace element in selected medicinal plants of north east India. J Appl Phys 2013;4:47-51.

2. Karimi A, Majlesi M, Rafieian-Kopaei M. Herbal versus synthetic drugs; beliefs and facts. J Nephropharmacol 2015;4:27-30.

3. Ekor M. The growing use of herbal medicines: Issues relating to adverse reactions and challenges in monitoring safety. Front Pharmacol 2014; 4:177.

4. Nema SS, Khaled AA, Nour El-Huda YH. Impact of toxic heavy metals and pesticide residues in herbal products. Beni Suef Univ J Basic Appl Sci 2016;5:102-6.

5. Vera D, Miomir $\dot{\mathrm{S}}$, Dijana $Đ$, Boban M. Investigation of heavy metals content in selected Tea brands marketed in Podgorica, Montenegro. Int J Pharm Sci Res 2016;7:4798-804.

6. Lajayer BA, Ghorbanpour M, Nikabadi S. Heavy metals in contaminated environment: Destiny of secondary metabolite biosynthesis, oxidative status and phytoextraction in medicinal plants. Ecotoxicol Environ Saf 2017;145:377-90.

7. Michaela Z, Iva JC. Trace determination of potentially toxic elements in (medicinal) plant materials review. Anal Methods 2017;9:1550-74

8. Pereira JB Jr., Dantas KG. Evaluation of inorganic elements in cat's claw teas using ICP OES and GF AAS. Food Chem 2016;196:331-7.

9. Subramanian R, Gayathri S, Rathnavel C, Raj V. Analysis of mineral and heavy metals in some medicinal plants collected from local market. Asian Pac J Trop Biomed 2012;2:574-8.

10. Kanda A, Ncube F, Kunsamala F. Investigation of some metals in leaves and leaf extracts of Lippia javanica: Its daily intake. J Environ Public Health 2017;2017:1-9.

11. Ibrahim MH, Kong YC, Zain NA. Effect of cadmium and copper exposure on growth, secondary metabolites and antioxidant activity in the medicinal plant sambung nyawa (Gynura procumbens (Lour.) merr). Molecules 2017;22:E1623.

12. Oloteju DA, Olalekan JK, Kayode SA, Gabriel AO, Manuel TM. Lead and cadmium contents in a medicinal plant/spice grown in an urban city of Nigeria. Cogent Food Agric 2016;2:1-8.

13. Aleksandra SS, Radmile P, Dragana J, Zoran D, Aleksandar S.
Heavy metals content in selected medicinal plants commonly used as components for herbal formulations. J Agric Sci 2015;21:317-25.

14. Gilbert UA, Adedoyin A. Evaluation of potentially toxic metal contamination of local medicinal plants and extracts sold in Ibadan/ Nigeria. J Health Pollut 2017;7:23-9.

15. Nazeer AR. Effect of Caesalpinia bonducella seed extract on histoarchitecture of some vital organs and clinical chemistry in female albino rats. J King Suad Univ Sci 2013;25:1-6.

16. Shruti S, Archana M, Pradeep M, Suresh PV, Vivek KB. Preliminary phytochemicals and antifungal screening of various organic extracts of Caesalpinia bonducella seeds. Rom Biotechnol Lett 2011;16:6384-9.

17. Deepika KS, Rama N, Meenakshi SM, Ravichandran N, David R, Brindha P. Evaluation of in vitro anticancer potential of ethanolic extract and its different fractions of Caesalpinia bonduc (L) Roxb seeds. Int J Pharm Pharm Sci 2014;6:311-4.

18. Komal M, Khadabadi SS, Deokate UA, Deore SL. Ceasalpinia bonducella $\mathrm{F}$ an overview. Rep Opin 2010;2:83-7.

19. Amudha P, Pushpa BN, Vanitha V. Caesalpinia bonducella a review on pharmacological and phytochemical activity of seeds. Int J Pharm Bio Sci 2016;7:674-80

20. Razia S, Rubina S, Nighat S. Characterization of the composition of Caesalpinia bonducella seed grown in temperate regions of Pakistan. J Am Oil Chem Soc 2012;89:1021-7.

21. Gupta M, Mazumder UK, Kumar RS, Sivakumar T, Vamsi ML. Antitumor activity and antioxidant status of Caesalpinia bonducella against Ehrlich ascites carcinoma in Swiss albino mice. J Pharmacol Sci 2004;94:177-84.

22. Ola B, Samreen F, Mohammed M, Mazahar F. Evaluation and photochemical and pharmacological properties of Cichorium intybus (L) Based on supercritical fluid extract. Res J Pharm Biol Chem Sci 2017;8:1857-66.

23. Sunita A, Sonam M. GC-MS profiling of Ceropegia bulbosa Roxb. Var Bulbosa, an endangered plant from Thar Desert, Rajasthan. Pharm Innov J 2017;6:568-73.

24. Salah AI, Ali HA, Imad HH. Spectral analysis and anti-bacterial activity of methanolic fruit extract of Citrullus colosynthis using gas chromatography-mass spectrometry. Afr J Biotechnol 2015;14:3131-58.

25. Zahra A, Alireza M, Jafar N, Mehdi H, Masoud Y, Mehdi A, et al. Effect of fertilizer application on soil heavy metal contamination. Environ Monit Assess 2010;160:83-9.

26. Yadav P, Prajapati PK. Quality control parameters for medicinal plants, an overview. Asian J Biomed Pharm Sci 2011;1:12-6.

27. Jay P, Kshetrimayum BS, Sanjiv K, Raj KM. Trace elements content in the selected medicinal plants traditionally used for curing skin diseases by natives of Mizoram, India. Asian Pac J Trop Med 2014;7:S410-4

28. Babalwa T, Opeoluwa OO, Ikechukwu PE, Adebola OO. Evaluation of trace metal profile in Cymbopogon validus and Hyparrhenia hirta used as traditional herbs from environmentally diverse region of Komga, South Africa. J Anal Methods Chem 2016;2016:1-8.

29. Koné WM, Koffi AG, Bomisso EL, Tra Bi FH. Ethnomedical study and iron content of some medicinal herbs used in traditional medicine in Cote D'ivoire for the treatment of anaemia. Afr J Tradit Complement Altern Med 2012;9:81-7.

30. Osredkar J, Sustar N. Copper and Zinc, biological role and significance of copper/zinc imbalance. J Clin Toxicol 2011;S3:2-18.

31. Manju M. Effects of heavy metals on human health. Int $J$ Res Granthaalayah 2015;3:1-7.

32. Giridhar BN, Raju TP, Srinivasu CC, Ramanamam V, Ram SS, Sudershan M, et al. Estimation of elemental concentrations of Indian medicinal plants using energy dispersive X-ray fluorescence (EDXRF). Int J Sci Eng Res 2015;6:1379-87.

33. Jasha MH, Petevino C. Trace elements analysis in some medicinal plants using graphite furnace-atomic absorption spectroscopy. Environ Eng Res 2016;21:247-55.

34. World Health Organization. WHO Guidelines for Assessing Quality of Herbal Medicines with Reference to Contaminants and Residues. Geneva: World Health Organization; 2007.

35. Adongo SO, Murungi J, Wanjau R. Determination of levels of selected essential elements in the medical plants used by Chuka community, Meru-Kenya using AAS. Int J Phys Soc Sci 2012;2:69-82.

36. Rathore JS, Upadhyay M. Investigation of Zinc concentration in some medicinal plant leaves. Res J Pharm Sci 2013;2:15-7.

37. Chen P, Bornhorst J, Aschner M. Manganese metabolism in humans. Front Biosci (Landmark Ed) 2018;23:1655-79.

38. Vijayalakshmi S, Kripa KG. Heavy metal analysis of Blepharis Maderaspatensis (L.) Heyne ex Roth. Asian J Pharm Clin Res 2018; 11:251-3. 
39. Huwait EA, Kumosani TA, Moselhy SS, Mosaoa RM, Yaghmoor SS. Relationship between soil cobalt and vitamin $\mathrm{B}_{12}$ level in the liver of livestock in Saudi Arabia: Role of competing elements in soils. Afr Health Sci 2015;15:993-8.

40. Szydłowski W, Łopatyński J. Biological role of chromium. Diabetol Pol 2003; 10:365-70.
41. Paul RY, Deepa K, Madhusudana RA, Reddeppa M, Shoha RT. Evaluation of trace elements in some medicinal plants: Jatropha, Albizia, Azadirachta indica and Datura plants. Eur J Pharm Med Res 2017;4: 455-65.

42. AYUSH. Permissible Level of Contaminants for AYUSH Standard Mark, Section III Annex C Version I. India: Foodcert India (P) Ltd.; 2011. 